\title{
С.Д. Борисова
}

\section{Распространение инвазионных видов с различными} статусами активности по территории Верхневолжья

\section{Аннотация}

Борщевик Сосновского Heracleum sosnowskyi Manden, видтрансформер, находится в списке видов со статусом І. Он активно внедряется в природные сообщества, меняет облик экосистем. Является эдификатором и доминантом. На большой площади образует заросли. Вытесняет прорастание других видов. И Недотрога железконосная - Impatiens glandulifera, Royle имеет статус II. Это адвентивный вид. Он активно расселяется и натурализируется в естественных и полуестественных местообитаниях. Установлено, что внедрение данных видов на территорию области и расселение по ее территории идет с юга на северо-запад и северо-восток.

Ключевые слова: инвазонныые растения, статус активности видов, Верхневолжье, макроуровень типизации агрогеосистем, ландшафтные провинции, Борщевик Сосновского Heracleum sosnowskyi Manden, Недотрога железконосная Impatiens glandulifera, Royle.

Heracleum sosnowskyi Manden, a transformer specie, is in the list of species with status I. It actively intrudes natural communities, changes the face of ecosystems. It is an edifier and dominant. It forms thickets over a large area. Displaces germination of other species. Impatiens glandulifera Royle has status II. This is an adventive specie. It is actively spreading and naturalizing in natural and semi-natural habitats. It has been established that the introduction of these species into the territory of the region and their dispersal over its territory proceeds from the south to the northwest and northeast.

Keywords: invasive plants, activity status of species, Upper Volga region, macrolevel of typification of agrogeosystems, landscape provinces, Heracleum sosnowskyi Manden, Impatiens glandulifera Royle.

UT нвазионный (инвазивный) вид - это вид, распространяющийся по территории как результат деятельности человека. Они вместе с культурами развиваются в одних и тех же природно-географических условиях. Поэтому, при изучении инвазионных видов необходимо не только изучать их биолого-морфологических признаки, но учитывать влияние природной среды на макро-, мезо- и микроуровне типизации агрогеосистем.

Под агрогеосистемой (АГС) следует понимать преобразованную антропогенно-геосистему, которая характеризуется условиями природной среды, окружающего ее геокомплекса определенного иерархического уровня, но еще и агроприродными особенностями сельскохозяйственного производства. Сорные растения (в том числе и инвазионные), наряду с культурными, являются неотъемлемой частью агрогеосистем, и поэтому изучать их не- обходимо в рамках определенных иерархических типизацонных уровней. Подробно типизация агрогеосистем Верхневолжья описана в следующих работах $[2 ; 3]$.

Основными макроединицами являются агроэкологические разделы (АР) - территории, границы которых совпадают с рубежами краев - крупных тектогенных единиц, обособляющихся в силу основных различий по неотектоническому режиму. Индикатором края является значительная морфографическая однородность рельефа и, следовательно, близкие абсолютные и относительные высоты, степень расчлененности и др., Территориально АР совпадает с ландшафтной провинцией (ЛП), но от нее отличается более углубленной характеристикой агропроизводственных условий. В его пределах целесообразно разворачивать региональную систему земледелия (РС3) - комплекс мероприятий по планированию и управлению АПК на макроуровне. 
Природное районирование. Сорно-полевые растения в природе по любым территориям распространены крайне неравномерно. Для выявления даже самых общих закономерностей необходимо изучаемую территорию разделить на ряд сравнительно однородных пространств. Существует много схем районирования, приведем некоторые из них.

На основании комплексного анализа данных естественного плодородия почв и экономических показателей административных районов в пределах Верхневолжья (Тверской области) выделены 4 природно-экономические зоны.

1. Северо-восточная зона это 8 административных районов: Бежецкий, Весьегонский, Кашинский, Кесовогорский, Краснохолмский, Молоковский, Сандовский, Сонковский. Рельеф местности здесь большей частью равнинный. Залесенность территории более слабая $34,4 \%$ по сравнению с другими зонами, болот $12,3 \%$ от общей площади болот области.

На этой территории более высокая сельскохозяйственная освоенность земель. Плодородие почв имеют более высокое. Почвы преимущественно дерновосреднеподзолистые легкосуглинистые на лессовидных суглинках.

Сумма положительных температур свыше $10^{\circ} \mathrm{C}$ в среднем $1700-1800^{\circ} \mathrm{C}$. Осадков за год выпадает 580-600 мм, а за период с температурой воздуха выше $10^{\circ} \mathrm{C}$ 275-356 мм. Гидротермический коэффициент 1,5-1,8. Продолжительность безморозного периода варьирует от 115 до 125 дней.

Однако, для изучения особенностей произрастания инвазивных видов необходимо оперировать более сложной схемой районирования территории, отражающей иерархическую соподчиненность и генезис агрогеосистем. Такая схема может быть создана только на основе вышеприведенной типизации.

2. Центральная зона включает в себя 10 административных районов: Калининский, Калязинский, Кимрский, Конаковский, Кувшиновский, Лихославльский, Максатихинский, Рамешковский, Спировский и Торжокский. Рельеф этой зоны равнинно-холмистый, с залесенностью 44,4\%, и заболоченностью $31 \%$ от всех болот области.

Почвы дерново-средне- и сильноподзолистые, суглинистого механического состава. занимают среднее место по плодородию. Содержание гумуса около 1,95\%. Много закамененных участков от 34 до 58\% площади зоны сильно- и среднекаменистые.

За период активной вегетации растений сумма среднесуточных температур воздуха выше $10^{\circ} \mathrm{C}$ варьирует в пределах $1800-1950^{\circ} \mathrm{C}$. Осадков за год выпадает 595721 мм., а за период с температурой выше $10^{\circ} \mathrm{C} 277-344$ мм. Гидротермический коэффициент составляет 1,5-18. Безморозный период длится 125-135 дней.

3. Северо-западная зона включает 13 административных районов области: Андреапольский, Бологовский, Вышневолоцкий, Жарковский, Западно-Двинский, Лесной, Нелидовский, Осташковский, Пеновский, Селижаровский, Торопецкий, Удомельский, Фировский.

Это холмистая территория, на которой имеются значительные понижения, занятые болотами. Основные типы почв здесь дерновосильно- и среднеподзолистые, торфяно-подзолисто-глеевые супесчаного и песчаного механического состава. Более $75 \%$ пашни с низкой и очень низкой кислотностью. На $36 \%$ площади пашни отмечается очень низкое содержание подвижного фосфора, а 49\% площаадей - обменного калия. Гумуса в пахотном горизонте здесь содержится около 1,82\%.

За период активной вегетации растений сумма эффективных среднесуточных температур воздуха свыше $10^{\circ} \mathrm{C}$ составляет $1770-1950^{\circ} \mathrm{C}$. Осадков за год выпадает 583-721 мм, из них за период вегетации 270-320 мм. Гидротермический коэффициент 1,5-1,8.

Сельскохозяйственная освоенность территории слабая (20.4\%), распаханность сельскохозяйственных угодий низкая $(9.5 \%)$. Это можно объяснить сложностью рельефа, залесенностью территории, пестрым механическим составом почв, высокой мелкоконтурностью и разбросанностью угодий между лессом и болотами. На полях отмечается высокая закамененность.

4. В состав Юго-западной зоны входит 5 административных районов области: Бельский, Зубцовский, Оленинский, Ржевский, Старицкий. Природно-климатические показатели для развития сельскохозяйственного производства здесь более благоприятны, чем в северо-западной зоне.

Рельеф здессь возвышенно-равнинный. Болота занимают 3,7\% от общей площади болот области, а леса покрывают 50,2\% территории. Следствием деятельности эрозионных процессов является высокая рассеченность зоны оврагами и балками. Площадь смытых почв находится в пределах $4,1-8,9 \%$ от общей площади сельскохозяйственных угодий. Сельскохозяйственная освоенность этой территории в 2 раза выше, чем в первой.

Основные типы почв зоны дерново-средне- и сильноподзолистые легкосуглинистые на покровных отложениях. Около 75\% почв с высокой кислотностью, 25-30\% с очень низким и низким содержанием подвижных форм фосфора и до 45-50\% имеет низкое содержание обменного калия. Гумуса в почвах здесь больше до 2,12\%.

Сумма среднесуточных температур воздуха выше $10^{\circ} \mathrm{C}$ составляет $1700-1950^{\circ} \mathrm{C}$. Осадков за год выпадает значительно меньше, чем в других зонах области - всего 580635 мм -. Гидротермический коэффициент 1,5 - 1,7. Продолжительность безморозного периода от 115 до 130 дней.

На территории Верхневволжья (Тверской области) насчитывается 4 ландшафтные провинции (агроэкологических раздела), территориально в основном совпадающих с вышеописанными зонами: Верхневолжская южной тайги, Верхневолжская смешанных лесов, Валдайская, Смоленско-Московская.

Инвазионные растения развиваются в тех же природно-географических условиях, что и культурные. Поэтому, при изучении их жизнедеятельности необходимо учитывать не только требования культурных растений, но и устройство природной среды на макро-, мезо- и микроуровне типизации агрогеосистем.

Борщевик Сосновского Heracleum sosnowskyi Manden., находится в списке видов со статусом I. Это виды-трансформеры [1], они активно внедряются в 
естественные и полуестественные сообщества, меняют облик экосистем, нарушают сукцессионные связи, являются эдификаторами и доминантами, образуют на большой площади заросли одно вида, вытесняют или препятствуют прорастанию других видов.

Борщевик Сосновского был завезён в центральную часть России, в том числе и на территорию Верхневолжья из Турции и Грузии в пятидесятых годах прошлого века. Из-за его огромных размеров растение планировали использовать в качестве кормовой культуры. Он должен был решить множество проблем, а превратился в первостепенное зло.

Животные ели силос из борщевика, но при этом качество молока, снизилось - оно приобрело горький вкус. Эксперимент свернули, но грамотно избавиться от данного вида, никто не подумал. Борщевик же при этом, очень вольготно стал себя чувствовать. Не просто прижился, а приступил к захвату всё новых и новых территорий.

И так, распространение борщевика Сосновского по территории Верхневолжья представлено на рис. 1.

Из данного рисунка видно, что по территории области борщевик распространен не равномерно. Мы посчитали средний балл по шкале активности для каждой ландшафтной провинции. Расчет рассмотрим на примере СмоленскоМосковской ландшафтной провинции. Провинция включает 5 административных районов, из которых в Бельском районе борщевик Сосновского имеет активность 2 балла, в Зубцовском, Оленинском, Ржевском и Старицком по 3 балла.

Посчитаем сумму баллов и поделим на количество районов.

$(2+3+3+3+3): 5=2,8$ Аналогично рассчитаем и по другим районам.

Результаты по другим провинциям представлены в таблице 1 .

Из таблицы видно, что наибольшую активность вид проявляет в СмоленскоМосковской ландшафтной провинции - 2,8, наименьшую в Верхневолжской южной тайги ландшафтной провинции - 1,5 балла.

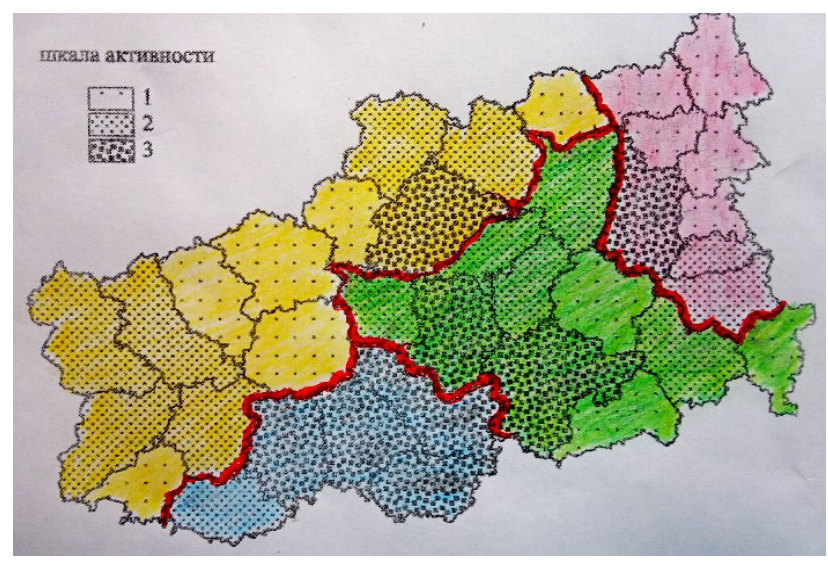

Таким образом, по данному виду можно предположить, что вид интенсивно захватывает новые территории с юга на северо-восток.

Недотрога железконосная - Impatiens glandulifera, Royle находится в списке видов со статусом II. Сюда относятся адвентивные виды, активно расселяющиеся и натурализирующиеся в нарушенных естественных и полуестественных местообитаниях [1]. Распространение недотроги железконосной по территории Верхневолжья представлено на рис. 1. Из рисунка видно, что активность едотроги по сравнению с борщевиком Сосновского значительно ниже и варьирует в пределах 1-2 баллов.

Таблица 1

Балл активности Борщевика Сосновского Heracleum sosnowskyi Manden и Недотроги железконосной - Impatiens glandulifera, Royle по агроландшафтным провинциям Верхневолжья

\begin{tabular}{|l|c|c|}
\hline \multicolumn{1}{|c|}{\begin{tabular}{c}
\multicolumn{1}{|c|}{ Ландшафтные } \\
провиции
\end{tabular}} & $\begin{array}{c}\text { Heracleum } \\
\text { sosnowskyi } \\
\text { Manden }\end{array}$ & $\begin{array}{c}\text { Impatiens } \\
\text { landulifera, } \\
\text { Royle }\end{array}$ \\
\cline { 2 - 3 } & \multicolumn{2}{|c|}{ Балл активности } \\
\hline $\begin{array}{l}\text { 1. Верхневолжский } \\
\text { южной тайги }\end{array}$ & 1,5 & 0,75 \\
\hline $\begin{array}{l}\text { 2. Верхневолжская } \\
\text { смешанных лесов }\end{array}$ & 1,9 & 1,1 \\
\hline 3. Валдайская & 1,6 & 0,77 \\
\hline $\begin{array}{l}\text { 4. Смоленско- } \\
\text { Московская }\end{array}$ & 2,8 & 0,8 \\
\hline
\end{tabular}

Попытаемся рассмотреть активность данного вида в пределах ландшафтных провинций Верхневолжья. Данные представлены в таблице 1.

Из таблицы видно, что активность недотроги по сравнению с борщевиком не высокая, но также наибольший показатель вида так же отмечается в Верхневолжской смешанных лесов ландшафтной провинции $-1,1$ балла. В СмоленскоМосковской так же есть один район - Зубцовский, в котором активность вида равна 2 и 2

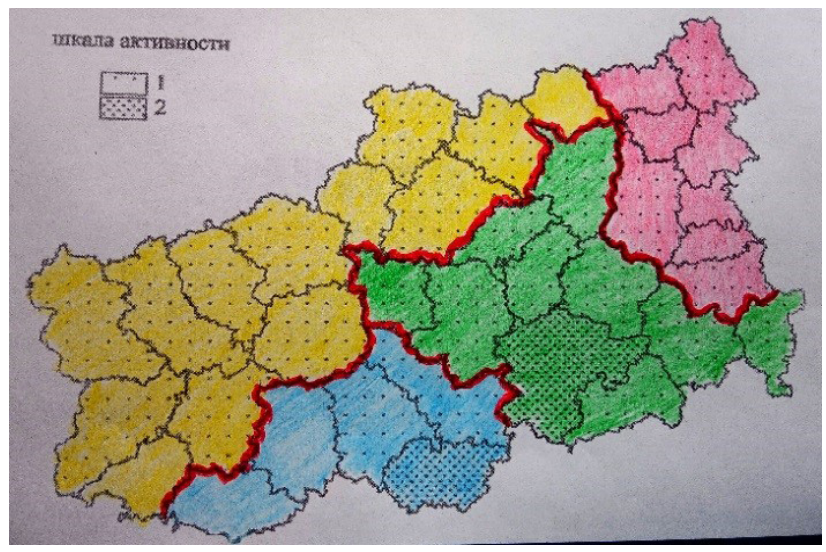

Рис. 1. - распространение Борщевика Сосновского Heracleum sosnowskyi

Manden. И недотроги железконосной - Impatiens glandulifera, Royle по территории Верхневолжья (условные обозначения: 1. Верхневолжский южной тайги - розовый; 2. Верхневолжская смешанных лесов - зеленый;

3. Валдайская - желтая; Смоленско-Московская - голубая ландшафтные провинции) 
района, по которым данные не приводятся (Бельский и Оленинский).

Таким образом, и по этому виду можно заключить, что внедрение его на территорию области и расселение по ее территории идет с юга на северо-запад и северо-восток.

Заключение.

В работе представлены 2 вида растений: Борщевик Сосновского Heracleum sosnowskyi Manden, находится в списке видов со статусом I. Это виды-трансформеры, они активно внедряются в естественные и полуестественные сообщества, меняют облик экосистем, нарушают сукцессионные связи, являются эдификаторами и доминантами, образуют на большой площади заросли одно вида, вытесняют или препятствуют прорастанию других видов. И Недотрога железконосная - Impatiens glandulifera, Royle находится в списке видов со статусом II. Сюда относятся адвентивные виды, активно расселяющиеся и натурализирующиеся в нарушенных естественных и полуестественных местообитаниях. Рассмотрены их морфолого-биологические особенности, а также распространение видов по территории Верхневолжья.

Установлено, что внедрение данных видов на территорию области и расселение по ее территории идет с юга на северо-запад и северо-восток.

\section{Литература}

1. Виноградова Ю.К. Черная книга флоры Тверской области: чужеродные виды растений в экосистемах Тверского региона / Ю.К. Виноградова, С.Р. Майоров. - М.: Товарищество научных изданий КМК, 2011. - 292 с.

2. Иванов Д.А. Анализ факторов, влияющих на произрастание малолетних сорняков в различных агроландшафтных условиях / Д.А. Иванов, А.Е. Родионова, Л.Ю. Юдкин // Вестник защиты растений. - СПб.: ВИЗР, 2000. - №1. - С. 112-114.

3. Иванов Д.А. Ландшафтно-адаптивные системы земледелия (Агроэкологические аспекты) / Д.А. Иванов. Тверь, 2001. -304 с.

\section{References}

1. Vinogradova, Iu. K., \& Maiorov, S. R. (2011). Chernaia kniga flory Tverskoi oblasti: chuzherodnye vidy rastenii v ekosistemakh Tverskogo regiona., 292. M.: Tovarishchestvo nauchnykh izdanii KMK.

2. Ivanov, D. A., Rodionova, A. E., \& Iudkin, L. Iu. (2000). Analiz faktorov, vliiaiushchikh na proizrastanie maloletnikh sorniakov v razlichnykh agrolandshaftnykh usloviiakh. Vestnik zashchity rastenii, 1, 112-114. SPb.: VIZR.

3. Ivanov, D. A. Landshaftno-adaptivnye sistemy zemledeliia (Agroekologicheskie aspekty)., 304. 